\title{
Germination of chia seeds submitted to saline stress
}

\author{
R. Stefanello ${ }^{a^{*}}$ (D), B. B. Viana (D), P. C. H. Goergen $^{b}$ (D), L. A. S. Neves ${ }^{a}$ (D) and U. R. Nunes ${ }^{b}$ \\ aDepartamento de Biologia, Centro de Ciências Naturais e Exatas, Universidade Federal de Santa Maria - UFSM, \\ Avenida Roraima, 1000, CEP 97105-900, Santa Maria, RS, Brasil

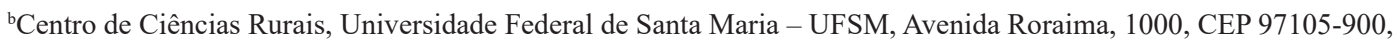 \\ Santa Maria, RS, Brasil \\ *e-mail: raquelstefanello@yahoo.com.br
}

Received: February 26, 2018 - Accepted: September 12, 2018 - Distributed: May 31, 2020

(With 2 figures)

\begin{abstract}
Salinity, of both soil and water, is one of the main causes of crop yield decline. Within this context, the objective of this study was to evaluate the influence of different salts on the germination of chia seeds. The experiment was conducted in a BOD chamber at a constant temperature of $20{ }^{\circ} \mathrm{C}$ and in the presence of light. The seeds were placed on paper soaked with aqueous solutions of calcium chloride $\left(\mathrm{CaCl}_{2}\right)$, sodium chloride $(\mathrm{NaCl})$, potassium chloride $(\mathrm{KCl})$, and magnesium chloride $\left(\mathrm{MgCl}_{2}\right)$, at the osmotic potentials zero, $-0.10,-0.20,-0.30$, and $-0.40 \mathrm{MPa}$. The effect of the salinity was evaluated using a germination test, with counts on days 7 and 14 after sowing. Based on the results, chia seeds tolerate concentrations of $\mathrm{NaCl}$ to $-0.4 \mathrm{MPa}$ and $\mathrm{KCl}$ to $-0.20 \mathrm{MPa}$. The salts $\mathrm{CaCl}_{2}$ and $\mathrm{MgCl}_{2}$ had a negative effect on the germination and vigor of the chia seeds for the osmotic potentials $-0.30 \mathrm{MPa}$ and $-0.20 \mathrm{MPa}$, respectively.
\end{abstract}

Keywords: Salvia hispanica, salinity, water.

\section{Germinação de sementes de chia submetidas ao estresse salino}

\section{Resumo}

A salinidade, tanto dos solos como das águas, é uma das principais causas da queda de rendimento das culturas. Neste contexto, o objetivo deste estudo foi avaliar a influência de diferentes sais na germinação de sementes de chia. $\mathrm{O}$ experimento foi conduzido em câmara BOD, na temperatura constante de $20^{\circ} \mathrm{C}$ e em presença de luz. As sementes foram colocadas sobre papel embebido em soluções aquosas de cloreto de cálcio $\left(\mathrm{CaCl}_{2}\right)$, cloreto de sódio $(\mathrm{NaCl})$, cloreto de potássio $(\mathrm{KCl})$ e cloreto de magnésio $\left(\mathrm{MgCl}_{2}\right)$ nos potenciais osmóticos correspondentes a zero; $-0,10 ;-0,20 ;-0,30$ e -0,40 MPa. O efeito da salinidade foi avaliado através do teste de germinação com contagens aos 7 dias e 14 dias após a semeadura. De acordo com os resultados é possível concluir que as sementes de chia toleram concentrações de $\mathrm{NaCl}$ até $-0,4 \mathrm{MPa}$ e $\mathrm{KCl}$ até $-0,20 \mathrm{MPa}$. Os sais $\mathrm{CaCl}_{2}$ e $\mathrm{MgCl}_{2}$ apresentam efeito negativo sobre a germinação e o vigor das sementes de chia a partir dos potenciais osmóticos de -0,30 MPa e -0,20 MPa, respectivamente.

Palavras-chave: Salvia hispanica, salinidade, água.

\section{Introduction}

Water is one of the most influential factors that can compromise seed germination because it is responsible for reactivating the metabolism and is involved in all stages of the germination process (Marcos-Filho, 2015). Tolerance to salinity during this process is crucial for establishing plants. However, the response of plants to excess salt depends on the species, genotype, and exposure time (Munns and Tester, 2008). In addition, the performance of plants under these conditions is influenced by osmotic and ionic effects that promote changes in metabolic activities of cells and in the stages of cellular elongation, which affects plant growth and in extreme cases can kill the organism (Taiz and Zeiger, 2013).
According to Javid et al. (2011) and Miransari and Smith (2014), salinity alters the hormonal equilibrium of a plant and an increase in salinity is associated to a decrease in auxin, cytokinin, gibberellin and salicylic acid in plant tissues, as well as an increase in abscisic acid and jasmonate. In addition, salt impairs seed germination in several ways, such as reducing water availability, changing the mobilization of stored reserves, and affecting the structural organization of proteins (Machado-Neto et al., 2004).

One of the most widespread methods of determining the tolerance of plants to excess salt is to observe germination in saline substrates. In this method, solutions that lower the osmotic potential of the water in the soil are used, which simulates an environment with reduced humidity 
and allows seeds submitted to negative osmotic potentials to be evaluated. This inhibits the germination potential of cultures, as found in the following studies: Plantago ovata Forssk. (Sousa et al., 2008); Salvia aegyptiaca L. (Gorai et al., 2011); Prosopis juliflora (Sw.) DC. (Nasr et al., 2011); Ochroma pyramidale (Cav. ex Lam.) Urb. (Dalberto and Braga, 2013); Salvia hispanica L. (Dal'Maso et al., 2013); Salvia splendens Sellow ex Roem. \& Schult. (Rosa et al., 2015); Vigna sinensis (L.) Savi (Kandil et al., 2017); Phaseolus vulgaris L. (Khatar et al., 2017); Portulaca oleracea L. (Naik and Karadge, 2017).

Studies related to germination response of seeds to conditions of artificial stress are important to agriculture and constitute tools that can evaluate the survival rate and adaptation of species to natural stress conditions (Guedes et al., 2013). In this context, chia seeds (Salvia hispanica L.), which have great nutritional importance and are widely consumed, were chosen for this study because there is little scientific work available about their development under conditions of saline stress. This species belongs to the family Lamiaceae, is native from central-west Mexico to northern Guatemala (Ayerza and Coates, 2004), and is commercially cultivated in Australia, Bolivia, Colombia, Guatemala, Mexico, Peru and Argentina (Busilacchi et al., 2013). In Brazil, the regions of western Paraná and northeastern Rio Grande do Sul recently started to invest in cultivating this species and have had good results, suggesting a promising future for this crop (Migliavacca et al., 2014).

Considering that obtaining knowledge about the best cultivation conditions and identifying the degree of salt tolerance of species is necessary when using water and soil affected by salts, and to expand the cultivation of $S$. hispanica in these areas, the objective of this work was to evaluate the influence of different salts on the germination of chia seeds.

\section{Material and Methods}

To evaluate the toxic effect of salts on the seed germination process, the chia seeds (Salvia hispanica), acquired from a company that produces and sells seeds in Burzaco, Argentina. The seeds were sown on a paper substrate moistened with aqueous solutions of calcium chloride $\left(\mathrm{CaCl}_{2}\right)$, sodium chloride $(\mathrm{NaCl})$, potassium chloride $(\mathrm{KCl})$ and magnesium chloride $\left(\mathrm{MgCl}_{2}\right)$, at osmotic potentials of zero (control), $-0.10,-0.20,-0.30$ and $-0.40 \mathrm{MPa}$. For the control (level zero), only distilled water was used. The quantity of the solution needed to obtain the osmotic potentials was based on Van't Hoff, as discussed by Taiz and Zeiger (2013) and Braccini et al. (1996). The toxic effect of salts on the seed germination process was evaluated using the tests listed below:

Germination (\%): conducted based on four repetitions of 100 seeds distributed in plastic boxes (gerbox), on germitest paper moistened with distilled water or saline solution (2.5 times the weight of the paper). After sowing the seeds, the plastic boxes were maintained in BOD chambers at a constant temperature of $20^{\circ} \mathrm{C}$ and $8 \mathrm{~h}$ of light and 16 hours of dark. Counts were made on days seven and 14 (when the test ended) and the results were expressed as percentage (Brasil, 2009).

First germination count $(\%)$ : conducted together with the germination test, where the percentage of normal seedlings was determined on day 7 of the test.

Data analysis: the experimental design was completely randomized, in a two factorial scheme, where treatments consisted of different salts and different concentrations of the solutions $(4 \times 5)$. The data was submitted to an analysis of variance using the F test and, when significant, a regression analysis was performed using the program Sisvar (Ferreira, 2011).

\section{Results and Discussion}

The analysis of variance indicated, for the germination and first count variables, there was significant interaction between the salt types and concentrations used (Table 1). In the absence of salt (control), the seeds had an average germination of $93 \%$, with significant differences depending on the treatments and salts used (Figure 1). When soaked in a solution of $\mathrm{NaCl}$ there was a discreet reduction in the germination percentage for the lowest osmotic potential used ( $79 \%$ in $-0.4 \mathrm{MPa})$, and in the presence of $\mathrm{KCl}$ there was a decrease in germination starting at $-0.20 \mathrm{MPa}$, which reached values lower than $50 \%$ (46\%) for the $-0.40 \mathrm{MPa}$ potential. In addition, the salts $\mathrm{CaCl}_{2}$ and $\mathrm{MgCl}_{2}$ inhibited germination of the chia seeds starting at the osmotic potentials $-0.30 \mathrm{MPa}$ and $-0.20 \mathrm{MPa}$, respectively. It is important to note that the effects of $\mathrm{CaCl}_{2}$ and $\mathrm{MgCl}_{2}$ on seed germination were more intense than $\mathrm{NaCl}$ and $\mathrm{KCl}$; although, independent of the water deficit inducing agent used, there was a reduction in germination percentage with an increase in salinity stress. According to Souza and Cardoso (2000), the chemical differences that exist among these solutions can cause changes in the germination and vigor results for seeds, even under similar water potentials.

In this study, the toxic effect of the salts was observed mainly in the presence of $\mathrm{MgCl}_{2}$, where the growth of roots (which also had dark tips) was inhibited starting at $-0.20 \mathrm{MPa}$. According to Nobre et al. (2010), excess salts cause the accumulation of ionic species that impair

Table 1. Summary of the analysis of variance, for the variables germination $(\mathrm{G})$ and first count $(\mathrm{FC})$, of chia seeds exposed to different concentrations of salts.

\begin{tabular}{cccc}
\hline Source of & \multirow{2}{*}{$\begin{array}{c}\text { Degrees of } \\
\text { variation }\end{array}$} & \multicolumn{2}{c}{ Mean square } \\
\cline { 3 - 4 } freedom & G & FC \\
\hline Salt & 3 & $17,377.94^{*}$ & $13,857.80^{*}$ \\
Treatment & 4 & $9,451.50^{*}$ & $9,572.50^{*}$ \\
Salt $\times$ Treatment & 12 & $2,377.21^{*}$ & $2,065.96^{*}$ \\
Residue & 60 & 3.89 & 4.00 \\
CV $(\%)$ & & 3.23 & 3.56 \\
\hline
\end{tabular}

*Significant at $5 \%$ probability by $\mathrm{F}$ test. $\mathrm{CV}=$ Coefficient of variation. 


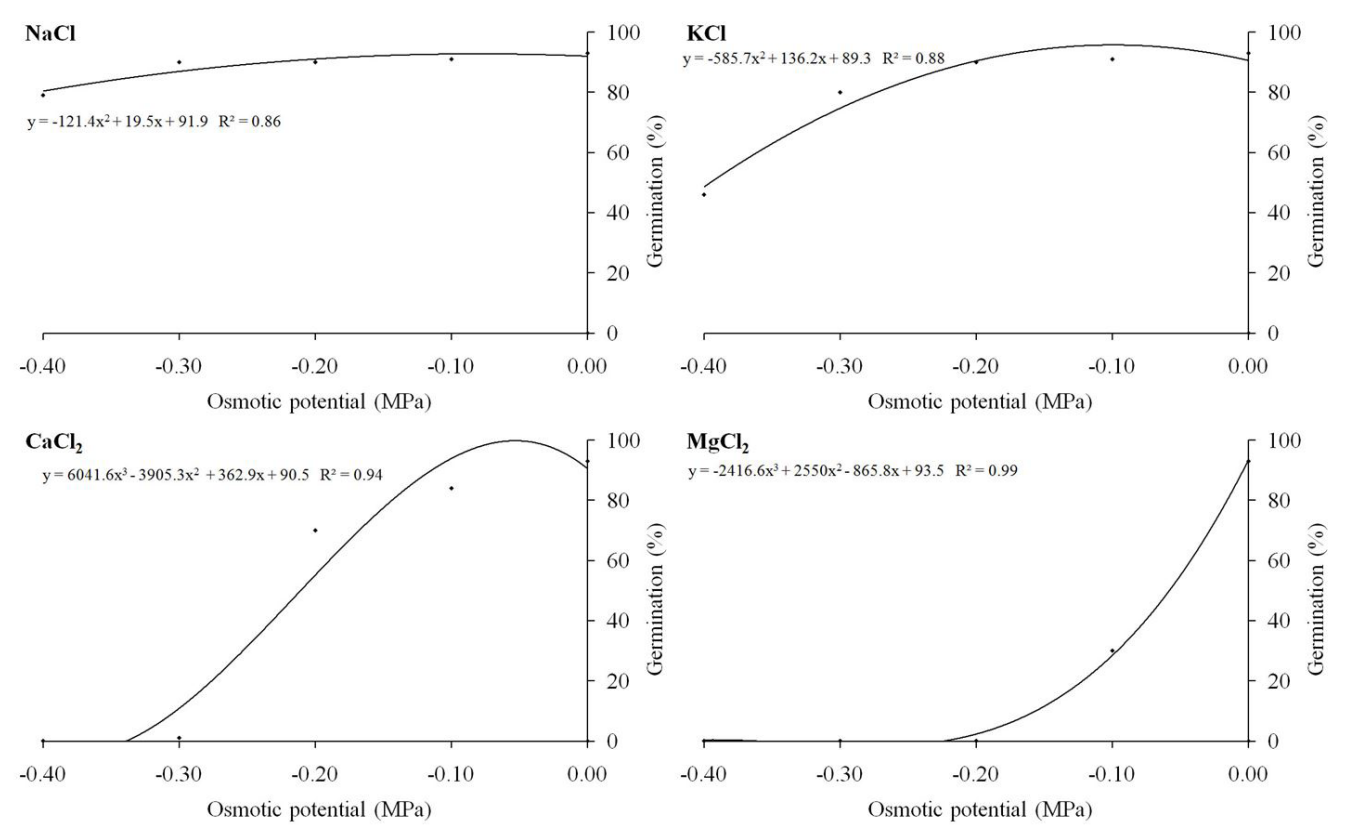

Figure 1. Percentage of germination of chia seeds exposed to different concentrations of salts.

the metabolism of plants, because the predominance of these ions in the root growth medium can be toxic when they accumulate in plant tissues and cause changes in the capacity of the plant to absorb, transport and use ions needed for growth.

The results of this work corroborate studies by Dalberto and Braga (2013) where osmotic potentials between -0.3 and $-0.4 \mathrm{MPa}\left(\mathrm{CaCl}_{2}\right)$ and -0.4 and $-0.5 \mathrm{MPa}(\mathrm{NaCl}$ and $\mathrm{KCl})$ inhibited seed germination of Ochroma pyramidale. Lavezo et al. (2015) worked with seeds of Petiveria alliacea L. and negative osmotic potentials of -0.4 and $-0.5 \mathrm{MPa}$ and found there was no germination when using $\mathrm{CaCl}_{2}$ and $\mathrm{NaCl}$ agents, respectively. In addition, Sousa et al. (2008) observed that the germination percentage of Plantago ovata seeds significantly decreased with potentials starting at $-0.4 \mathrm{MPa}$ of $\mathrm{NaCl}$ and $\mathrm{CaCl}_{2}$, and Rosa et al. (2015) analyzed seeds of Salvia splendens and observed elevated indices of seed death and abnormal seedlings in the presence of $\mathrm{NaCl}$ and $\mathrm{KCl}$. On the other hand, some studied have demonstrated that chia seeds tolerate certain levels of salinity, such as Dal'Maso et al. (2013) (KCl).

The reduction in germination percentage is due to the high concentration of solutes in the solution, which is a stress factor to the plants because saline solutions promote a water deficit by retaining water in the solution, and an increase in the concentration of these solutes makes the water less available to the plants. Consequently, a high concentration of salts in cells can deactivate enzymes, inhibit protein synthesis, and impede seed germination (Nasr et al., 2011; Taiz and Zeiger, 2013).

Seed vigor, evaluated by the first germination count test, decreased with increased concentrations of the saline solutions (Figure 2). A discreet reduction in the percentage of normal plants was observed starting with the potentials $-0.10 \mathrm{MPa}(\mathrm{NaCl})$ and $-0.20 \mathrm{MPa}(\mathrm{KCl})$, reaching values of 68 and $33 \%$, respectively, for the lowest concentration used $(-0.40 \mathrm{MPa})$. In addition, normal plants were not observed starting with the potentials $-0.30 \mathrm{MPa}$ and $-0.20 \mathrm{MPa}$ for solutions of $\mathrm{CaCl}_{2}$ and $\mathrm{MgCl}_{2}$, respectively.

Results in the literature show that salinity has a negative effect on the percentage of normal plants and emergence of various cultures, such as Atriplex nummularia Lindl. (Ruiz and Parera, 2013), Piptadenia stipulacea (Benth.) Ducke (Nogueira et al., 2014), Petiveria alliacea L. (Lavezo et al., 2015), Orobanche crenata Vell. (Moral et al., 2015), Cucumis sativus L. (Albuquerque et al., 2016), and Zea mays L. (Silva et al., 2016). Toxic concentrations of these ions $\left(\mathrm{Na}^{+}, \mathrm{K}^{+}, \mathrm{Ca}^{2+}, \mathrm{Mg}^{2+}\right)$ affect other physiological and metabolic processes of embryonic tissues, including cellular division and differentiation, enzyme activity, and the uptake and distribution of nutrients. Ionic toxicity can also lead to delayed seedling emergence and mobilization of reserves or to a decrease in the viability of seeds (Esteves and Suzuki, 2008; Munns and Tester, 2008).

The chia seeds were sensitive to the exposure to different salts at osmotic potentials between -0.1 and $-0.4 \mathrm{MPa}$, which was observed by the decrease in germination and vigor. This information is important to help understand where this species can be grown, since the regions where it is cultivated will be exposed to less rainfall (due to climate change), poor irrigation techniques, inadequate fertilization, as well as organic residues in the soil that can have high levels of salts and, consequently, affect the establishment of the crop. 

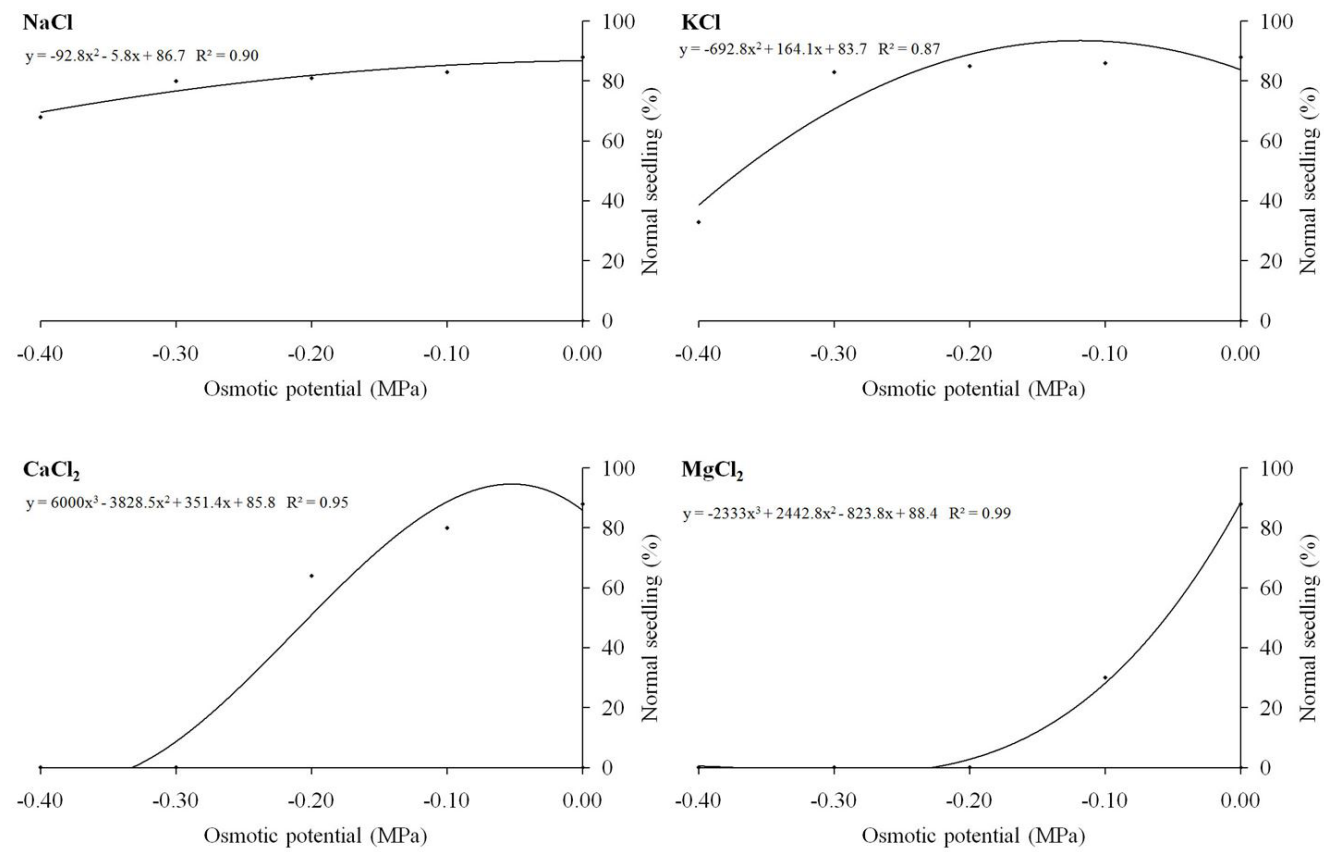

Figure 2. First germination count of chia seeds exposed to different concentrations of salts.

\section{Conclusions}

Chia seeds tolerate concentrations of $\mathrm{NaCl}$ to $-0.4 \mathrm{MPa}$ and $\mathrm{KCl}$ to $-0.20 \mathrm{MPa}$. The salts $\mathrm{CaCl}_{2}$ and $\mathrm{MgCl}_{2}$ had a negative effect on the germination and vigor of the chia seeds for the osmotic potentials $-0.30 \mathrm{MPa}$ and $-0.20 \mathrm{MPa}$, respectively.

\section{References}

ALBUQUERQUE, J.R.T., SÁ, F.V.S., OLIVEIRA, F.A., PAIVA, E.P., ARAÚJO, E.B.G. and SOUTO, L.S., 2016. Crescimento inicial e tolerância de cultivares de pepino sob estresse salino. Revista Brasileira de Agricultura Irrigada, vol. 10, no. 2, pp. 486-495. http://dx.doi.org/10.7127/rbai.v10n200355.

AYERZA, R. and COATES, W., 2004. Composition of chia (Salvia hispanica) grown in six tropical and subtropical ecosystems of South America. Tropical Science, vol. 44, no. 3, pp. 131-135. http://dx.doi.org/10.1002/ts.154.

BRACCINI, A.L., RUIZ, H.A., BRACCINI, M.C.L. and REIS, M.S., 1996. Germinação e vigor de sementes de soja sob estresse hídrico induzido por soluções de cloreto de sódio, manitol e polietilenoglicol. Revista Brasileira de Sementes, vol. 18, no. 1, pp. 10-16. http://dx.doi.org/10.17801/0101-3122/rbs.v18n1p10-16.

BRASIL, 2009. Regras para análise de sementes. Brasília: Secretaria de Defesa Agropecuária, Ministério da Agricultura, Pecuária e Abastecimento. 395 p.

BUSILACCHI, H., BUENO, M., SEVERIN, C., DI SAPIO, O., QUIROGA, M. and FLORES, V., 2013. Evaluacion de Salvia hispanica L. cultivada en el sur de Santa Fe (República Argentina). Cultivos Tropicales, vol. 34, no. 4, pp. 55-59.

DAL'MASO, E.G., CASARIN, J., COSTA, P.F., CAVALHEIRO, D.B., SANTOS, B.S. and GUIMARÃES, V.F., 2013. Salinidade na germinação e desenvolvimento inicial de sementes de chia. Cultivando o Saber (Cumaná), vol. 6, no. 3, pp. 26-39.

DALBERTO, D.S. and BRAGA, L.F., 2013. Estresse osmótico e putrescina na germinação de sementes de Ochroma pyramidale (Cav. Ex Lam) Urb (Malvaceae). Cientifica (Jaboticabal), vol. 41, no. 2 , pp. 99-110.

ESTEVES, B.S. and SUZUKI, M.S., 2008. Efeito da salinidade sobre as plantas. Oecologia Australis, vol. 12, no. 4, pp. 662-679. http://dx.doi.org/10.4257/oeco.2008.1204.06.

FERREIRA, D.F., 2011. Sisvar: a computer statistical analysis system. Ciência e Agrotecnologia, vol. 35, no. 6, pp. 1039-1042. http://dx.doi.org/10.1590/S1413-70542011000600001.

GORAI, M., GASMI, H. and NEFFATI, M., 2011. Factors influencing seed germination of medicinal plant Salvia aegyptiaca L. (Lamiaceae). Saudi Journal of Biological Sciences, vol. 18, no. 3, pp. 255-260. http://dx.doi.org/10.1016/j.sjbs.2011.01.004. PMid:23961132.

GUEDES, R.S., ALVES, E.U., VIANA, J.S., GONÇALVES, E.P., LIMA, C.R. and SANTOS, S.R.N., 2013. Germinação e vigor de sementes de Apeiba tibourbou submetidas ao estresse hídrico e diferentes temperaturas. Ciência Florestal, vol. 23, no. 1, pp. 45-53. http://dx.doi.org/10.5902/198050988438.

JAVID, M.G., SOROOSHZADEH, A., MORADI, F., SANAVY, S. and ALLAHDADI, I., 2011. The role of phytohormones in alleviating salt stress in crop plants. Australian Journal of Crop Science, vol. 5, no. 6, pp. 726-734

KANDIL, A.A., SHAREIF, A.E. and GAD, M.A., 2017. Effect of salinity on germination and seeding parameters of forage cowpea seed. Research Journal of Seed Science, vol. 10, no. 1, pp. 17-26.

KHATAR, M., MOHAMMADI, M.H. and SHEKARI, F., 2017. Some physiological responses of wheat and bean to soil salinity 
at low matric suctions. International Agrophysics, vol. 31, no. 1, pp. 83-91. http://dx.doi.org/10.1515/intag-2016-0028.

LAVEZO, A., BRAGA, L.F., BATISTÃO, A.C. and BONFANTE, L.V., 2015. Estresse osmótico na germinação de sementes de Petiveria alliacea L. Revista Brasileira de Plantas Medicinais, vol. 17, no. 4, pp. 622-630. http://dx.doi.org/10.1590/1983084X/14_026.

MACHADO-NETO, N.B., SATURNINO, S.M., BOMFIM, D.C. and CUSTÓDIO, C.C., 2004. Water stress induced by mannitol and sodium chloride in soybean cultivars. Brazilian Archives of Biology and Technology, vol. 47, no. 4, pp. 521-529. http://dx.doi. org/10.1590/S1516-89132004000400004.

MARCOS-FILHO, J., 2015. Fisiologia de sementes de plantas cultivadas. 2. ed. Londrina: Abrates. 659 p.

MIGLIAVACCA, R.A., SILVA, T.R.B., VASCONCELOS, A.L.S., MOURÃO FILHO, W. and BAPTISTELLA, J.L.C., 2014. O cultivo da chia no Brasil: futuro e perspectivas. Journal of Agronomic Sciences, vol. 3, no. spec., pp. 161-179.

MIRANSARI, M. and SMITH, D.L., 2014. Plant hormones and seed germination. Environmental and Experimental Botany, vol. 99, pp. 110-121. http://dx.doi.org/10.1016/j.envexpbot.2013.11.005.

MORAL, J., LOZANO-BAENA, M.D. and RUBIALES, D., 2015. Temperature and water stress during conditioning and incubation phase affecting Orobanche crenata seed germination and radicle growth. Frontiers in Plant Science, vol. 6, pp. 408. http://dx.doi.org/10.3389/fpls.2015.00408. PMid:26089829.

MUNNS, R. and TESTER, M., 2008. Mechanism of salinity tolerance. Annual Review of Plant Biology, vol. 59, no. 1, pp. 651681. http://dx.doi.org/10.1146/annurev.arplant.59.032607.092911. PMid:18444910.

NAIK, V.V. and KARADGE, B.A., 2017. Effect of $\mathrm{NaCl}$ and $\mathrm{Na}_{2} \mathrm{SO}_{4}$ salinities and light conditions on seed germination of purslane (Portulaca oleracea Linn.). Journal of Plant Stress Physiology, vol. 3, pp. 1-4. http://dx.doi.org/10.19071/jpsp.2017.v3.3142.

NASR, S.M.H., PARSAKHOO, A., NAGHAVI, H. and KOOHI, S.K.S., 2011. Effect of salt stress on germination and seedling growth of Prosopis juliflora (Sw.). New Forests, vol. 42, no. 1, pp. 9265-9269.

NOBRE, R.G., GHEYI, H.R., CORREIA, K.G., SOARES, F.A.L. and ANDRADE, L.O., 2010. Crescimento e floração do girassol sob estresse salino e adubação nitrogenada. Ciência Agronômica, vol. 41, no. 3, pp. 358-365. http://dx.doi.org/10.1590/ S1806-66902010000300006

NOGUEIRA, F.C.B., BEZERRA, M.L., PINHEIRO, C.L. and MEDEIROS FILHO, S., 2014. Piptadenia stipulacea (Benth.) Ducke seed germination in response to temperature, light and water stress. American Journal of Plant Sciences, vol. 5, no. 26, pp. 3796-3804. http://dx.doi.org/10.4236/ajps.2014.526397.

ROSA, D.B.C.J., SOARES, J.S., MORENO, L.B., MICHELS, G.S., LEMES, C.S., SCALON, S.P.Q. and ROSA, Y.B.J., 2015. Germinação de Salvia splendens L. submetida à salinidade. Ornamental Horticulture (Campinas), vol. 21, no. 1, pp. 105-112. http://dx.doi.org/10.14295/rbho.v21i1.782.

RUIZ, M.B. and PARERA, C.A., 2013. Efecto del estrés hídrico y salino sobre la germinación de Atriplexnum mularia (Chenopodiaceae). Acta Biologica Colombiana, vol. 18, no. 1, pp. 99-106.

SILVA, R.C., GRZYBOWSKI, C.R.S. and PANOBIANCO, M., 2016. Vigor de sementes de milho: influência no desenvolvimento de plântulas em condições de estresse salino. Ciência Agronômica, vol. 47, no. 3, pp. 491-499. http://dx.doi.org/10.5935/18066690.20160059

SOUSA, M.P., BRAGA, L.F., BRAGA, J.F. and DELACHIAVE, M.E.A., 2008. Estresse hídrico e salino no processo germinativo das sementes de Plantago ovata Forsk. (Plantaginaceae). Revista Árvore, vol. 32, no. 1, pp. 33-38. http://dx.doi.org/10.1590/S010067622008000100005 .

SOUZA, G.M. and CARDOSO, V.J.M., 2000. Effects of different environmental stress on seed germination. Seed Science and Technology, vol. 28, no. 3, pp. 621-630.

TAIZ, L. and ZEIGER, E., 2013. Fisiologia vegetal. 5. ed. Porto Alegre: Artimed. 954 p. 